\title{
Embedding ecosystem services ideas into policy processes: an institutional analysis
}

\author{
Duncan J. Russel ${ }^{1}$ and John Turnpenny ${ }^{2}$
}

\begin{abstract}
What helps or limits the use of ecosystem services ideas in practice? In this paper we develop and test a new institutionalistbased analytical scheme to explore how ecosystem services as a "new" policy idea might interact with established policy regimes, processes, and norms. The scheme is based on three different decision-making levels: micro, meso, and macro. To test the plausibility of the scheme, it is applied to the case of the UK where a specific ecosystem services framework (ESF) was prioritized as a new way of doing environmental policy after 2011. Drawing on findings from 32 elite interviews, the paper shows how dynamics at all three levels intersect with differing institutional explanations. It helps explain important factors for embedding, or restricting embedding, of the ESF in policy making. The scheme provides a useful way to link analysis of the "lived experience" of policy actors implementing the ESF with the institutional landscape they occupy, and allows for a nuanced and integrated analysis of the potential barriers faced by ecosystem services ideas generally.
\end{abstract}

Key Words: ecosystem services framework; embedding; environmental policy making; institutionalism

\section{INTRODUCTION}

Ideas to better capture the value of the natural environment in the form of ecosystem services (e.g., Costanza et al. 2014, Rafaelli 2016) have a long history and a rich variety of disciplinary origins (Turnpenny and Russel 2017). But the path from idea to policy is not always smooth. Studying the influence or lack thereof of particular ideas on policy processes, and factors that affect this influence, forms a large and growing area of literature in political studies (Schmidt 2008, Parsons 2016). Moreover, recent work in this journal (Noe et al. 2017, Challenger et al. 2018, Nordin et al. 2017, Waylen et al. 2015) and elsewhere (e.g., Jordan and Russel 2014, Turnpenny and Russel 2017) has shown that embedding ideas about more ecologically sensitive policy making can be far from easy. The role institutions such as established policy regimes, processes, and norms play in facilitating or blocking the influence of new ideas in policy processes is an old question. As Margaret Weir (1992) noted, institutions create opportunities for innovation but bound what types are possible. This is particularly the case for environmental policy making, replete with ideas about problems and solutions, cutting across multiple policy areas such as transport, water, energy, and agriculture (Carter 2018). Crudely, therefore, new environmental policy ideas such as ecosystem services often encounter "a lot of institution" when attempts are made to use them to influence policy change. We develop an exploratory analytical scheme to understand the different institutions (Peters 2016) that may confront ecosystem services ideas when attempts are made to better capture the value of the environment in policy decision-making processes. To test the scheme, we apply it to the empirical case of the implementation of the United Kingdom's 2011 Natural Environment White Paper (Defra 2011). Our main aim is not to provide a definitive explanation of this case. Rather, we illustrate the utility of our scheme in drawing attention to different institutional processes that can be in play, and point to further areas of research to provide more detailed explanations.
There are several reasons for using the UK case. The White Paper drew on analysis from a government-sponsored National Ecosystem Assessment (NEA 2011), with the UK being one of the first countries (Waylen and Young 2014) to conduct such an assessment. The White Paper aimed at a major change in how environmental goals were delivered through policy making. At its core were a reduced focus on direct regulation, while better capturing environmental value (both monetary and nonmonetary) to society through an ecosystem services framework (ESF) based around a more integrated approach to environmental management. In this context, the ESF aimed at better understanding of "the processes that link human societies and their wellbeing with the environment" (NEA 2011:15). The White Paper said "[ministries] will be open about the steps they are taking to address biodiversity and the needs of the natural environment, including actions to: promote, conserve and enhance biodiversity; and reduce the environmental impacts of food and catering services" (Defra 2011:43).

One might imagine such a policy idea that was well-established conceptually and had emerged from well-respected scholarship (MEA 2005, NEA 2011), and was given a clear national policy steer, would be implemented in a widespread fashion. But the embedding of the ESF required ministries to adopt new institutional processes and practices to better capture ecological value in their activities, through, for example, data collection, ex ante appraisal of policies and evaluation mechanisms (see for instance Turnpenny and Russel 2017). And the ESF, while relatively simple in its basic concept, has been shown to have multiple different ideas attached to it in both theoretical debates and policy practice (Turnpenny and Russel 2017). It has also been repeatedly argued that the UK has fallen short of its ambitious environmental policy goals, due in part to institutional constraints (Russel and Jordan 2008). In sum, we suggest the great expectations around the White Paper were particularly likely to encounter a wide range of institutional challenges. Given the

${ }^{1}$ Department of Politics, University of Exeter, UK, ${ }^{2}$ School of Politics, Philosophy, Language and Communication Studies, University of East Anglia, UK 
above, rather than choosing a definition of ESF a priori, we focus on the term as it was actually used, and explore the various interpretations through "lived experience" of what ESF is in different institutional contexts as part of the empirical research. This allows for multiple interpretations and reasons for (not) embedding or using the ESF as it was differently understood.

\section{IDEA-INSTITUTION RELATIONSHIPS: AN ANALYTICAL SCHEME}

Institutions are critical for embedding new policy ideas and associated processes and practice (Oliver and Pemberton 2004, Béland 2005, 2009, Kern 2011, Peters 2016). We follow Scharpf's (1997:38) definition of institutions as "systems of rules, norms and cultural systems of meaning that shape the courses of action." Crucially, as Béland (2009) observes, institutions define "rules of the game" and associated political opportunity structures. As such, institutions can constrain and create opportunities depending on how ideas fit with existing institutional rules (Kern 2011), and challenge powerful actors (Béland 2009).

Various strands of institutionalism have emerged in the past three decades offering different explanatory perspectives (Peters 2016). In this paper, we draw on three commonly used strands (Hall and Taylor 1996, Peters 2016) in which decision-making logics emerge through institutional processes that shape values that in turn lead to the creation of norms: the development of set behavior-based practices and actions and attitudes toward those practices. However, each strand has a different rationale in terms of what drives the logics. A rational choice institutionalist explanation is based on actors behaving, according to their (given) preferences, to optimize utility within the constraints established by institutions. Institutions here are purposefully constructed to ensure a collectively rational outcome that would not materialize if everybody acted individually on their preferences, a "logic of consequence" (Peters 2016). By contrast, a sociological institutionalist explanation is based on collective decision making driven by "what one can imagine oneself doing" (Hall and Taylor 1996:948, Peters 2016) in particular contexts. The institutions here are values-based routinized norms that dictate decision rules, and frames of meaning. In this "logic of appropriateness," actors behave, through a process of socialization, according to the surrounding institutions. Agency is lower than in a rational choice explanation, but not zero because institutions are still actively created and refined, although not necessarily with the same degree of preference-satisfying purpose. Third, a historical institutionalist explanation is based on the "logic of path dependency": outcomes are dependent on the structural history of decision making (Peters 2016). Institutions are said to be "sticky" and hard to change because of embedded power relationships, political authority, and the weight of past decisions. Actors are therefore argued to be objects and agents of history meaning that agency is lower still than in a sociological explanation. More recently, different approaches have opened up (Lowndes and Roberts 2013). In place of various institutionalist strands offering competing explanations, the strands are more often used to illuminate different elements of common themes, such as rules, practices, and narratives (Lowndes and Roberts 2013) that cross all strands. In this approach, "the character of constraint ... is an empirical rather than an ontological matter" (Lowndes and Roberts 2013:76): "As actors encounter institutions ... they are likely to be motivated by (some combination of) their selfish interests, their 'need to belong', and their underlying ideas and values" (Lowndes 2018:71).

In this spirit, we build on the work of Turnpenny and Russel (2017), following an inductive exploratory approach to examine how institutional dynamics operating at three different decisionmaking levels embody different strands of institutionalism, and are thus crucial to influencing how the ESF is embedded in policy making. The micro level is concerned with the individual behavior of policy makers who have to engage with the ESF: their behavior and the resource constraints (e.g., expertise, professional background, timescale, awareness, understanding) that bear upon them. As Berman (1998, as cited in Oliver and Pemberton 2004) notes, ideas need transmitters, individuals or groups, to promote the idea, influence behavior, and build coalitions (also see Béland 2005). However, institutions place constraints on the actions (Torfing 2001) of individual actors in policy making because of the informal and formal policy making rules often operating at a higher meso level. The meso level is concerned with organizational dynamics, including organizational procedures and management structures, systems of knowledge transfer, norms and incentive structures, and interorganization competition. Behavior is driven by formal and informal policy making rules, and goals of policy making organizations. Among other things, rules make it possible to coordinate simultaneous activities, avoid conflict, and help to mitigate against unpredictability (March and Olsen 1989), and to reduce "the time and energy otherwise used on thousands of decisions about how to perceive and evaluate an otherwise unintelligible stream of information" (March and Olsen 1996:253). Although over time or in times of acute crisis, these rules and routines can change, it is said that they tend to have a "surprising durability," which gives the impression of inertia. The macro level is concerned with the wider political, economic, and social context, including dominant values, norms, and goals. Institutional organization of the polity, society, and the economy structures behavior, and promotes certain values and ideas over others (Weir and Skocpol 1985, Hall and Taylor 1996).

The levels clearly interact; there is no assumption that the macro level provides the overarching societal and political structure within which decisions at other levels are taken. And each level may contain evidence of differing institutionalist explanations. The ways that institutional explanations and different levels interact with, and shape, each other in the attempts to embed the ESF in UK policy making is an empirical question addressed in the rest of this paper. Our claim is the three levels approach provides a relatively simple way to obtain empirical information because levels are intuitively familiar to policy actors, the ways they work, and the structures they work within. Moreover, we seek to probe the plausibility (Eckstein 1975) of the levels approach as a way to link analysis of the lived experience of policy actors trying to embed the ESF in their own words with different potential institutional explanations embedded therein.

\section{METHODS}

In this paper we employ the elite interview method (Richards 1996) and draw on 32 interviews with a range of experts within the UK in 2013/2014. This was the period immediately following the Natural Environment White Paper and National Ecosystem 
Assessment: a period that might be expected to have high recognition and traction of the ESF as an idea, but where existing institutions seem to have experienced significant challenges (Turnpenny and Russel 2017). The period was a time of flux, and idea-institution dynamics might be expected to be most interesting. In this context, it was important to explore how the interviewees interpreted the ESF and its required integrating into decision making. To ensure a range of perspectives was captured, a classification of policy advisors was used to select interviewees. Howlett (2011:33), synthesizing literature on policy advisors and advice systems, proposed two dimensions as being particularly important in classifying policy advisors: "their location inside or outside of government, and ... how closely they operate to decision-makers." Combining these dimensions results in four communities of policy advisors. These were adopted in this paper: Core Actors such as government officials and policy analysts (labelled as interviewees A1 to A15 in the empirical sections below); Public Sector Insiders such as commissions, task forces, research councils, advisory bodies (labelled B1 to B6); Nongovernmental Insiders such as consultants carrying out policy appraisals ( $\mathrm{C} 1$ to $\mathrm{C} 4$ ); and Outsiders, e.g., businesses, trade associations, third sector organizations, independent academics, think tanks (D1 to D7). Interviews followed a semistructured format around several headline questions (see Appendix 1) to allow for both comparability and flexibility (see Bryman 2016). These questions were broad enough to test points raised in the literature, while simultaneously avoiding steering or leading the interviewees. The conversations were led by each interviewee's experiences and knowledge. The interviews were conducted either face-to-face or via telephone. Interview summary transcripts were produced shortly after each interview.

Analysis of the data was guided by the questions asked in the semistructured interviews, which built upon the research questions and analytical scheme. Following the interviews, the data underwent thematic analysis, a technique widely used in the qualitative social sciences (Nowell et al. 2017) for "identifying, analyzing, organizing, describing, and reporting themes found within a data set (Braun \& Clarke, 2006)" (Nowell et al. 2017:2). Thematic analysis is especially useful for ensuring the researcher follows a consistent and well-structured strategy for sorting qualitative data (King 2004). Following established approaches (e.g., see Nowell et al. 2007) both authors (1) read and became very familiar with our interview transcripts and rechecked against the original recordings; (2) established an initial set of meta codes based on step one to guide step three. Broad themes were identified around barriers and enablers to embedding, including aspects such as valuation, bureaucratic burden, and resources; (3) revisited the themes in the data for a more fine-grained analysis so that subthemes emerged. For example the broad theme of valuation contained subthemes including individual concerns about the ethics of valuing nature, social resistance to valuing nature, and concerns about the accuracy of environment value data; (4) finalized the themes and checked all data assigned to themes for consistency; (5) documented the themes in relation to the research questions and analytical scheme, drawing on the detailed theoretical foundations (see above) to guide us to where the different themes fit. All stages were conducted by two researchers independently to check for consistency. Consistency and reliability were also aided by the use of our interview selection strategy where respondents with different relationships to the ESF and the policy processes could be triangulated (Bryman 2016) within the identified themes to see where perspectives were similar or differed depending on different affiliations (see also Nowell et al. 2017).

\section{RESULTS}

\section{Micro level}

From our data, two main findings emerged at the micro level. First, it did not necessarily benefit an individual to understand or be aware of a new idea. Interviewees ${ }^{[1]}$ talked about the difficulties they faced in getting colleagues to fully understand the ESF and relate it to their work. For example one interviewee remarked, "People internally find [the ESF] difficult to grasp. It is the current sexy term but people struggle to understand what it means" [Interviewee A3].

Five $^{[2]}$ interviewees also spoke of low awareness of the issue in general amongst colleagues. Both the issues of understanding and low awareness may have been a product of the technical nature of the ESF, but, under a rational logic, struggling with the concept might in some cases have been a deliberate tactic. Choosing not to understand, to avoid having to address the issues ESF raises around valuing nature ${ }^{[3]}$ and consequent burden or threat, demonstrated a strong degree of agency. There is evidence that hierarchical imposition of an idea could have been resented as extra work, with a resulting barely minimal compliance, "Sticks tend to result in tick boxes" [interviewee A2].

The added value of the ESF was also questioned even by individuals working in the natural environment sector. Three interviewees ${ }^{[4]}$ suggested this may be because the ESF represented a threat to professional expertise, and by implication jobs, particularly in the environment sector. Another clue to why ESF may have been seen as a threat comes from a more sociological institutionalist perspective. How was the new idea congruent with a norm of expected behavior by policy makers, or by those employing them? For example, one interviewee expressed skepticism about the chance of embedding ESF in existing policy making processes, as ESF was regarded purely as "economics in some people's minds" [A13]. In a similar vein, four ${ }^{[5]}$ interviewees thought that the ESF was mainly an exercise in quantificationand thus, "... people resist it because they think it is just about monetizing biodiversity which runs against their core values" [B2].

It is not clear from the data whether this interpretation of the ESF was deliberate or not. This distinction might be important because it implies different logics at play, namely a more rational one for a deliberate misinterpretation of the concept, and a more sociological one where established processes for interpreting new knowledge shape how that knowledge is understood.

Points raised by some respondents ${ }^{[6]}$ about a lack of suitable data for handling the ESF might indicate a similar issue: policy makers were expected to draw on unfamiliar concepts, made more difficult by lack of complete supporting information. An uncomfortable expectation of being able to handle this could have led to a lack of engagement.

The second main finding at the micro level was the emerging resource gap for addressing the new idea of ESF. Several 
respondents ${ }^{[7]}$ spoke of an individual skills gap for dealing with the type of analysis that the ESF entails. A rational institutionalist perspective might question the extent to which it benefitted organizations to rearrange their skills profiles in response to a new idea, before checking carefully that this would continue to benefit the organization. A historical institutionalist explanation is also pertinent: another five interviewees ${ }^{[8]}$ observed that because the established structure of UK government tended to compartmentalize skills across all levels of government, experts had limited opportunity to work together on ESF-related matters. As one respondent put it,

At the moment skills are siloed, meaning for example that an economist working on one place may not be properly linked-up with an ecologist working on the same place at the moment. So, we need to integrate section skills [A4].

\section{Meso level}

Several findings emerged at the meso level. First was the role of timing. The applicability of the ESF to existing decision-making timescales was questioned by some interviewees ${ }^{[9]}$ in two senses: administrative timescale differences, and differences between shorter term electoral-cycle driven concerns (often based around economics) and longer time frames of environmental protection. Overcoming historically-established ways of handling timescales was crucial ${ }^{[10]}$. One perspective was that change simply takes time [11]: "There has been 25 years of culture of doing these things the way they are..., so to turn the ship around might take some time" [D2].

Second, departmental resistance, ambivalence, or boundarydrawing was seen as a key issue for diffusion of the ESF into nonenvironment departments whose work had an impact on ecosystems quality ${ }^{[12]}$. A strong drawing of boundaries was seen by one interviewee as a rational response to avoiding being overwhelmed with extra work: "This is interesting stuff, but there is no evidence of its value to us" [A2]. Another interviewee noted the diluting of one's own ministry with another's agenda:

Although the [Environment] White Paper is a
government document, it is clearly perceived by other
departments as [the Environment Ministry's] White
Paper. It's not got the other government departments
interested. They still see it as the [Environment
Ministry's] or the environment sector's agenda so they
are not joining up policy for the holistic view present in
the White Paper. This makes implementing it not very
easy [B4].

Skepticism of the utility of helping another department achieve its policy goals would not be unexpected from a rational institutionalist perspective. The cross-cutting nature of the ESF as outlined in the 2011 Natural Environment White Paper meant that its implementation would use resources from different ministries, to the detriment of achieving their own core goals, while the Environment Ministry's utility would be enhanced by passing the responsibility for action on to others.

Third, and similar to the micro level, the ESF was seen as a burden and distraction for the organization as a whole, and therefore rationally treated similarly to the way an individual policy maker might: as a tick-box exercise rather than an opportunity to approach policy making in a different way ${ }^{[13]}$. But a sociological institutional perspective can help interpret $14^{[14]}$ interviewees' point that the ESF was not particularly congruent with the organization's decision-making norms, expressed by querying the ESF's applicability to various decision-making situations and project areas even in the environmental sector. Such situations included, for example, simple amendments to policy or in situations where EU policy had to be transposed.

You start to run into existing practices and ways of doing things. If you are actually doing nothing it is easier to bring in the ESF. But where you already have existing approaches you get adaptation rather than significant change [B2].

In this sense, interviewees spoke of existing policies that did not reflect the joined-up more flexible nature of the ESF, such as national (and European) policies and approaches that promoted the in-situ regulation of the management of sites of special scientific interest or nature reserves rather than an integrated more adaptable way of ecological management. In a similar vein, the European Union's Common Agricultural Policy was not geared toward the ESF, being more concerned with environmental protection and production through farmer support.

We also observed incongruence between ESF and organizations' decision-making norms related to a lack of sustained leadership from ministers, senior civil servants, executive officers, and central government departments ${ }^{[15]}$. Indeed, one interviewee noted open hostility amongst management in his institution:

\section{The high command tried to sabotage the ESF as it runs against the reductionist and managerialist culture of [my institution]. The ecosystems [framework] is thus seen as inconvenient. So they make the appearance of implementing the ESF, but in reality they may or may not be [B1].}

Fourth, the match (or not) of the new idea with existing processes was important. Three particular types of mismatch were evident: of the concept, of structures and of terminology. Many interviewees ${ }^{[16]}$ were negative about the concept of the ESF, mainly on the basis of the rational critique of whether it really added value to existing policy-making processes. Some interviewees $^{[17]}$ for instance wondered whether the ESF was something (i.e., greater environmental protection) that had been attempted (albeit in different guises such as sustainable development) many times before, suggesting a form of historical path-dependency. For one (Interviewee A6) it was seen as an empty buzzword. Others questioned whether employing an ESF led to better decisions, or whether it added anything to what they were doing already. For example, one commented, "The common question is invariably, what is it that we should be doing different internally?"[B2]. Although interviewees questioned the utility of the ESF, it was noted by some respondents that regardless of the concept's utility, "[the environment ministry] has spent a great deal of money in promoting [the ESF] and so they have to have a practical outcome" [C1], giving evidence of maximizing returns from sunk costs.

The mismatch of structures formed another significant challenge: whether the ESF was compatible or not with historically entrenched institutional arrangements. In some cases, this was 
framed as a structural problem in terms of institutional fragmentation and the existence of silos, “... the planning system doesn't address agriculture and forestry. These are not covered by planning and are the responsibility of a different department" [C1].

Fragmented institutional arrangements have a history and thus traction; the consequence of this, according to interviewees ${ }^{[18]}$, was that policy was often not joined up, which could impede the ESF as an idea. Crucially there were a lack of institutional platforms for discussing the management of ecosystems limiting the opportunity of learning across institutional silos (Interviewee $\mathrm{C} 2$ ).

Finally, a mismatch of terminology between the ESF and the more practical context of policy making was raised ${ }^{[19]}$. For instance, one interviewee remarked:

\section{... at the moment, the concept is so nebulous there is a danger that it won't be meaningful.... If I have 10 experts in a room, I will currently get 10 different approaches [C2].}

The issue of language was compounded by a lack of clear terminology ${ }^{[20]}$, with weakly defined concepts like shared social values, natural capital, environmental valuation, and various related terms such as the ecosystems approach, tended to muddy the waters and create ambiguous targets for policy makers. This meant that for these interviewees there was a lot of confusion over what the implementation of the ESF in a specific context entailed. For example, did they have to establish and appraise environmental values, did they have to produce a natural capital stocktake, did they need to have a more joined up approach to ecosystem management? Some interviewees suggested that academics should more simply and better define their concepts:

... we operate in an academic world, so there is a lot of jargon of language and terms surrounding the [ESF]. As things develop, we need to be less worried about the specifics of jargon. Even if we are not quite talking in the same terms, are we pushing in the same direction? [A2].

Thus, we saw conflicting understandings between academics and policy makers, operating within different contexts and expectations of their profession groups, of the appropriate conceptualizations of the ESF.

\section{Macro level}

Similar to both micro and meso levels was the sense of burden or threat emerging from a new idea at the macro level. Speaking to a more rational logic, the role of political steering was observed by five of our respondents ${ }^{[21]}$, which they argued affected the embedding of the ESF. Politicians responding to public pressures, party politics, manifesto commitments and crises pushed for their preferred policy outcome. In such situations embedding the ESF into policy was seen by some to have been heavy-handed or indeed superfluous ${ }^{[22]}$. In these cases, one interviewee (B1) argued that such pressures meant that the ESF was seen as a threat for overtly rationalist political reasons, which led to resistance. This could manifest itself through a desire to appear to implement while not actually doing so, using the requirement for, for example, proportionality in policy making as an excuse to keep the new idea away.

Our findings showed that broader political priorities during the period studied tended to concentrate on economic issues such as austerity in public spending, and reducing the regulatory burden ${ }^{[23]}$, to reduce costs and impacts of policy on business and society. These high-profile macro-level policy discourses and strategy undermined efforts to mainstream the ESF in policy making. For instance, according to one interviewee (A5), new procedures or regulations may have contradicted broader political priorities. As another interviewee's rationalist interpretation of this problem argued, "[the government is keen to] not let environmental regulation get in the way of infrastructure development and housing" [B4]. This trend was argued by three respondents ${ }^{[24]}$ to have worsened during the environment of austerity, which placed further pressure on resources.

Our findings also revealed a more sociological institutional element to why the ESF may have been seen as an inappropriate way to frame environmental problems, thus hampering its traction in policy making. Environmentally sympathetic people may be put off by the perceived economic framing and question the underlying ethics of valuing nature in monetary terms, arguing that nature has a right to exist or be valued beyond its services to humans ${ }^{[25]}$. Moreover, to some respondents the whole notion of the ESF contrasted with broader values of society, which generally prioritized factors other than ecosystems such as wealth creation, health, job security, and car-friendly transport policy ${ }^{[26]}$.

\section{DISCUSSION}

In this paper we sought to build upon the literature on the difficulties faced when embedding ideas to better capture the value of the natural environment into policy. We have examined the role of institutional dynamics, in the form of established policy regimes, processes, and norms. The paper used a caseembedding the ESF in the UK in the period immediately following the 2011 Natural Environment White Paper-as a plausibility probe (Eckstein 1975) for an analytical scheme based on different institutional levels: individual behavior (micro), organizational dynamics (meso), and wider social and political context (macro).

\section{Micro-level institutional dynamics}

Institutions offer incentives and disincentives for certain types of individuals' interventions and behaviors, for example how far dealing with the issues associated with policy ideas can help achieve formal goals and positive career progression for policy officials (Hall and Taylor 1996). In relation to this aspect, we found low awareness of the ESF concept despite some strong signaling by the core executive, suggesting that the concept was a long way from helping policy makers achieve formal goals. Moreover, institutional prioritization shapes how much human and time resources are available to policy makers to collect suitable data related to the policy idea, and to integrate this data into their policy making (Turnpenny et al. 2008, Russel and Jordan 2009). From our data it appeared that actions at a micro level were bounded by individuals' low understanding of the concept, and/or deliberate subversion, in some cases intentionally choosing not to understand the concept of the ESF as a professional or organizational threat. It appeared that individual action may be bound by "congealed preferences" relating to rational logics of consequence where decisions are framed around achieving rational instrumental goals and efforts to reduce transaction costs of action (Torfing 2001). Sociologically constructed "logics of appropriateness," through which images, symbols, and rituals combine to form rules of behavior that can lead to the development of shared meaning (Morgan 1997:132) 
or to "webs of meaning" (Marsh et al. 2001:21), were also revealed at the micro level. These included some of the expected norms of policy makers that led them to reject (or embrace) the economic analysis elements of the ESF, on the basis of their professional identity (Torfing 2001) and beliefs (Hall and Taylor 1996). Another factor that can bound action is the supply of information to decision makers (Hall and Taylor 1996, Torfing 2001). As our data imply, information asymmetries and data gaps made it difficult for policy makers to understand the impacts of a policy idea in their sector and the relevance to the policy at hand (Turnpenny and Russel 2017). In relation to this point and our data, a "logic of appropriateness" may also help explain the observed perceived lack of suitable data: the economic data available on the value of the environment was in conflict with resistance to "pricing the environment." Moreover, individual policy makers have a bounded cognitive capacity and are only capable of processing and interpreting a given amount of data (Simon 1985, Béland 2005). The ability to focus on a few core issues at once may account for the observed low awareness and ambivalence within our data. Overall, if an issue raised by a new policy idea is not seen as core to an official's job, it can easily be ignored.

\section{Meso-level institutional dynamics}

Rules for handling and embedding new policy ideas at the meso level may develop for a number of reasons: from a logic of consequence structuring interactions to stop free-riding and pursue organizational goals, from a logic of appropriateness in which webs of meaning shape the rules through which networks and collectives of policy-making actors interpret policy ideas (Hall and Taylor 1996), and/or from a logic of path dependency. In this latter historical institutionalist perspective, rules are structured around past policy decisions and practices, creating path dependency and institutional stickiness. Institutional rules act as external constraints that define the repertoire not the choice of action (Torfing 2001) and as such structure the range and sequence of alternative actions when confronting policy making (Hall and Taylor 1996).

All manifest in our data. There was a mismatch between the structured decision-making timescales and the longer timeframes associated with the ESF. Moreover, rules can structure what is considered a legitimate course of action (Torfing 2001), or legitimate evidence to support action (Juntti et al. 2009). Within the data, the observation that ESF was the Environment Ministry's agenda seemingly provoked a rationalist reaction undermining the ESF's legitimacy, viewing it instead as a threat by other ministries. We observed a questioning of the utility of the ESF, and whether it really represented something different. Rules either allow space (rule in) or crowd out (rule out) certain ideas, depending on how the issue fits with established practice (Torfing 2001, Russel and Jordan 2009). Rules also shape the relations and interactions of the subunits of an organization, which may have a set of complementary but also different and conflicting rules (Richards and Smith 2002). This pattern was manifest for example in the observed mismatch between the ESF and other organizational norms; the ESF was observed to run against established practice. There was similarly an observed mismatch between ESF and historical institutional structures, which made embedding ESF in important departments (even within the environment ministry) difficult. In such situations where rules conflict between subunits, departmental pluralism or departmentalism (Russel and Jordan 2009) can develop where the cross-cutting initiative or idea enthusiastically taken up in one part of the organization does not fit with the rules of another, leading in some cases to conflict and active resistance, over the questioning of the added value of the approach. The data also showed that sociologically constructed webs of meaning created different understandings of both the problem the ESF attempted to address and the proposed solutions to said problems, between different institutions of science and between the institutions of science and policy making (also see Turnpenny and Russel 2017).

\section{Macro-level institutional dynamics}

Power asymmetries, allowing some groups disproportionate access to policy making over others (Hall and Taylor 1996), can lead to the creation of constraints and opportunities for embedding new ideas (Béland 2005), as the historical sequence of decisions structure political debate and related dominant paradigms and values in society (Béland 2005). In such situations, problems can arise with the embedding of new ideas into policy making if that issue is too far from a dominant policy paradigm. As Niemelä and Saarinen (2012) note, this maintenance of the dominant norms is akin to the production of cognitive locks, so rather than a change in policy making approach, policies and existing institutions are reproduced over time. Thus there is a risk of path dependency (Hall and Taylor 1996), whereby new policy ideas are rejected to reduce the risk of instability at the macro level. Here we see in our data the perception that the ESF was a threat from a rational institutionalist perspective. In this understanding, utility-maximizing politicians responded to public and interest group pressures for reduced policy burden, especially in times of economic difficulty as in this case study. Thus, the ESF was employed in an attempt to appease environmental interests, but not in a way that was disruptive to traditional policy concerns around the economy. New ideas can also contradict entrenched societal norms about what is an important or appropriate subject to consider. In such circumstances, even if change is initiated it is marginal as the new ideas are built upon pre-existing political, societal, and economic paradigms that dominate a sector and/or wider society (Torfing 2001, Niemelä and Saarinen 2012). Again, we can see examples of this in our data, including on the one hand wariness of valuing nature in the environmental sector, and on the other an explicit prioritizing of nonenvironmental issues among wider societal groups in the period studied.

\section{Developing and using the analytical scheme}

The levels-based analytical scheme, for the case studied, has helped link analysis of the lived experience of policy actors working with the ESF in their own words with different potential institutional explanations embedded therein, adding layers of nuance, as well as offering a practical approach to empirical enquiry. It seems to confirm the claim that "each [of the strands of NI] seems to be providing a partial account of the forces at work in a given situation" (Hall and Taylor 1996:955). In so doing, the scheme does not imply that one institutional logic is at play more than the other, or at specific levels. Rather, it combines related but different institutional perspectives to explore the types of responses that a new environmental policy idea might encounter. 
Table 1. What might we hear when a new idea comes up against existing institutions?

\begin{tabular}{|c|c|c|c|}
\hline $\begin{array}{l}\text { Institutional } \\
\text { logic }\end{array}$ & $\begin{array}{l}\text { Micro level: } \\
\text { individual behavior }\end{array}$ & $\begin{array}{l}\text { Meso level: } \\
\text { organizational dynamics }\end{array}$ & $\begin{array}{l}\text { Macro level: } \\
\text { wider social and political context }\end{array}$ \\
\hline Rational & $\begin{array}{l}\text { CELL 1: "How far does } \\
\text { Idea X help me as an } \\
\text { individual?" }\end{array}$ & $\begin{array}{l}\text { CELL 2: "How far does Idea } \\
\text { X help our organization / unit } \\
\text { / team protect core resources / } \\
\text { influence / budget?" }\end{array}$ & $\begin{array}{l}\text { CELL 3: "How far does Idea X help } \\
\text { meet wider political and societal } \\
\text { preferences?" }\end{array}$ \\
\hline Historical & $\begin{array}{l}\text { CELL 4: "How familiar } \\
\text { am I with Idea X?" }\end{array}$ & $\begin{array}{l}\text { CELL 5: "How does Idea X } \\
\text { challenge established decision- } \\
\text { making roles and } \\
\text { competencies?" }\end{array}$ & $\begin{array}{l}\text { CELL 6: "How does Idea X } \\
\text { challenge established societal } \\
\text { structures, ideas, and power } \\
\text { relations?" }\end{array}$ \\
\hline Sociological & $\begin{array}{l}\text { CELL 7: "How far is Idea } \\
\mathrm{X} \text { consistent with what is } \\
\text { expected of me?" }\end{array}$ & $\begin{array}{l}\text { CELL 8: "How far is Idea X } \\
\text { consistent with how we make } \\
\text { decisions in our organization / } \\
\text { unit / team?" }\end{array}$ & $\begin{array}{l}\text { CELL 9: "How far is Idea X } \\
\text { consistent with wider social norms?" }\end{array}$ \\
\hline
\end{tabular}

How might the scheme be used in other cases? Table 1 summarizes the kinds of responses that might be encountered when listening to policy actors' views about a new environmental policy idea, across the nine intersections between institutional logics and levels.

At the micro level, if the answer to the question in Cell 1 is "no," idea X may be seen as a burden or a threat, and likely to be resisted by the individual. Idea $\mathrm{X}$ is also likely to be resisted if the individual policy actor is unfamiliar with it (Cell 4). In Cell 7, expectations on the individual may come from a variety of sources, colleagues, management, social norms, but to overcome barriers to embedding, idea X should fit with policy makers' expectations of what is appropriate activity. At the meso level, in Cell 2, the implication is the organization, unit, or team will check to see if they can still maximize their utility in the face of idea X. In Cell 5, the source of the entrenchment can come as a result of exercise of power ("we'll tread on other departments' toes") or of simple repetition ("this isn't our job, it's Ministry A's"). The implications are that idea X could either fit with entrenched decision-making structures, challenge these in a way that leads to resistance, or challenge these at critical junctures and enable embedding of the idea. In Cell 8 , idea $X$ is more likely to be embedded if it fits with organizational decision-making norms, such as how evidence is collected, when evidence is collected, what type of evidence to collect, different approaches and timings in relation to governmental and nongovernmental stakeholders' involvement, etc. At the macro level, in Cell 3, ideas that contradict socio-political preferences would be a threat to utility. In Cell 6, as in Cell 5, an idea's degree of fit with entrenched decision-making structures would influence the embedding of the idea. In Cell 9, idea $\mathrm{X}$ is likely to need to fit with social norms to become embedded.

The scheme we propose does not necessarily resolve how both the dynamics at the institutional levels and the drivers of these dynamics interact. There is clearly interaction between the levels. For example, individual responses to the idea are determined/ shaped by meso-level organization dynamics and these are in turn shaped by wider social preferences and values such as whether or not to monetize the natural environment. Interactions also occur in different directions; for instance, a lack of resources / expertise (micro) can influence how far an organization sees an idea as a concept worth taking seriously (meso). Individual responses are also shaped by an individual's position within one of the four distinct communities of policy advisors, whether they identify with more than one community, and how well-established their position and influence is. More directly, such positioning may also influence the views gathered and reported in this paper. Points made above by a wide range of types of interviewee may be seen as less likely to reflect an individual's own circumstances.

Moreover, the explanations embedded within the different strands of institutionalism will interact in a manner that requires further exploration. For instance, the extent to which policy processes stem from the rational management of complexity in the policy sphere, a logic of appropriateness, or historical legacy is not a question our scheme can necessarily resolve on its own. The scheme's usefulness rather lies in revealing different factors present in any chosen case as a way to direct subsequent more explanatory research. Exploring first which cells in Table 1 are present and to what degree can guide development of more detailed research questions around, for example, which institutionalist explanation is most strongly at play in a given case. In this way, our scheme is more research-question-generating than question-answering.

Which interesting cases might be examined in such a way? Although we showed a limited uptake of the ESF and many institutional constraints in the period studied, there has since been significant presence of the ideas behind the ESF in national and local policy in the UK that shows that despite the difficulties of embedding the ESF, the idea still has traction. For example, initiatives have included the creation of Nature Improvement Areas in 2016, which seek to create joined up and resilient ecological networks at a landscape scale to provide clear economic and social benefits (Natural England 2016). The 25 Year Environment Plan (HM Government 2018), promised a new cross-government approach to governing the environment based on the notion that environmental protection and enhancement is crucial to social and economic well-being. An expert Natural Capital Committee was established in 2012 and reappointed for a second term in 2016 whose role is to advise government and oversee the 25 Year Environmental Plan in relation to sustainable use of natural capital including the benefits the economy and society derive from nature (HM Government 2016). These 
developments suggest that institutional contexts are not fixed, they can change significantly over time, although this change may be slow (Peters 2016, Turnpenny and Russel 2017). Future research could explore what institutional changes have happened over time, why, and the impact these have had on uptake of the idea of ESF. A particular area of focus could be on any gap between policy steer and what happens on the ground; as this paper has shown, the inclusion of the ESF in policy documents does not necessarily mean it is being carried out in practice. For example, the above-mentioned 25-year Environment Plan has been criticized for being full of good intentions but lacking legally binding targets, underpinning legislation and specific practical solutions (EAC 2018). Drawing on institutional analysis future research could posit that such plans might not amount to much in practice in the short term because they will be heavily dominated by the institutional process they encounter. These could include inadequate resources or rewards for pursuing the idea of ESF, lack of support from senior staff, or contradictory messages at ministerial or cabinet level, among many others. The dynamics of if/how these factors change over time could be revealed using the scheme in Table 1 informing both more explanatory research question development and more targeted approaches by policy actors to overcome such barriers. For example, for Cell 1 a suitable strategy might be to link the ESF to career progression, spending, or budgets. Likewise, the logics described in Cell 5 might be countered by dedicated training and censure for failing to adopt the ESF norms. We, therefore, present Table 1 as consolidation of our exploratory approach so that more deductive analysis can be pursued in other critical environmental policy initiatives from a local to a global scale, and where appropriate targeted strategies can be developed to improve implementation on the basis of the analysis. Overall, the resulting more detailed and integrated accounts would not only provide new academic insights but could be useful in devising policy strategies for environmental policy that are more sensitive to institutional environments in which they are expected to perform.

${ }^{[1]}$ Interviewees: A3, A4, A15, B2, C1, C2, C3, C4, D3, D5, D7

${ }^{[2]} \mathrm{A} 11, \mathrm{~A} 12, \mathrm{~A} 13, \mathrm{~A} 15, \mathrm{~B} 4$

${ }^{[3]} \mathrm{A} 2, \mathrm{~B} 1$

${ }^{[4]} \mathrm{A} 5, \mathrm{~B} 1, \mathrm{C} 2$

${ }^{[5]} \mathrm{B} 2, \mathrm{C} 3, \mathrm{C} 4, \mathrm{D} 2$

${ }^{[6]} \mathrm{A} 3, \mathrm{~A} 4, \mathrm{~A} 7, \mathrm{~B} 2, \mathrm{~B} 3, \mathrm{~B} 4, \mathrm{~B} 5, \mathrm{C} 3, \mathrm{C} 4, \mathrm{D} 2, \mathrm{D} 3$

${ }^{[7]} \mathrm{A} 1, \mathrm{~A} 3, \mathrm{~A} 15, \mathrm{~B} 2, \mathrm{C} 1, \mathrm{C} 2, \mathrm{C} 3, \mathrm{D} 3$

${ }^{[8]} \mathrm{A} 4, \mathrm{~A} 12, \mathrm{C} 2, \mathrm{C} 3, \mathrm{D} 2$

${ }^{[9]} \mathrm{A} 4, \mathrm{~A} 8, \mathrm{~A} 15, \mathrm{~B} 1, \mathrm{~B} 2, \mathrm{~B} 3, \mathrm{C} 1, \mathrm{C} 3, \mathrm{D} 3, \mathrm{D} 5, \mathrm{D} 7$

${ }^{[10]} \mathrm{B} 2$

${ }^{[11]} \mathrm{B} 2, \mathrm{D} 4$

${ }^{[12]} \mathrm{A} 2, \mathrm{~A} 5, \mathrm{~A} 11, \mathrm{~B} 4, \mathrm{C} 1, \mathrm{D} 6$

${ }^{[13]} \mathrm{A} 14, \mathrm{~B} 3$

${ }^{[14]} \mathrm{A} 1, \mathrm{~A} 3, \mathrm{~A} 4, \mathrm{~A} 8, \mathrm{~A} 11, \mathrm{~A} 12, \mathrm{~A} 14, \mathrm{~A} 15, \mathrm{~B} 3, \mathrm{~B} 4, \mathrm{~B} 5, \mathrm{C} 1, \mathrm{C} 2, \mathrm{D} 3$

${ }^{[15]} \mathrm{A} 4, \mathrm{~A} 2, \mathrm{~B} 1, \mathrm{~B} 4, \mathrm{D} 4$

${ }^{[16]} \mathrm{A} 6, \mathrm{~A} 10, \mathrm{~A} 14, \mathrm{~A} 15, \mathrm{C} 1, \mathrm{C} 2, \mathrm{C} 3, \mathrm{D} 4, \mathrm{D} 7$

${ }^{[17]} \mathrm{A} 5, \mathrm{~A} 7, \mathrm{~A} 14, \mathrm{~B} 2, \mathrm{~B} 3, \mathrm{C} 2, \mathrm{D} 6$

${ }^{[18]} \mathrm{A} 5, \mathrm{~A} 14, \mathrm{C} 1, \mathrm{D} 3$

${ }^{[19]} \mathrm{A} 4, \mathrm{~A} 12, \mathrm{C} 2, \mathrm{C} 3, \mathrm{D} 2$

${ }^{[20]} \mathrm{A} 4, \mathrm{~A} 8, \mathrm{~A} 14, \mathrm{C} 1, \mathrm{C} 2, \mathrm{C} 3, \mathrm{C} 4, \mathrm{D} 3, \mathrm{D} 7$

${ }^{[21]} \mathrm{A} 6, \mathrm{~A} 8, \mathrm{~A} 11, \mathrm{~A} 12, \mathrm{D} 3$

${ }^{[22]} \mathrm{A} 11, \mathrm{~A} 12$
${ }^{[23]} \mathrm{A} 2, \mathrm{~A} 6, \mathrm{~A} 12, \mathrm{~B} 3, \mathrm{~B} 4, \mathrm{~B} 5, \mathrm{C} 1, \mathrm{D} 1, \mathrm{D} 2, \mathrm{D} 3, \mathrm{D} 5, \mathrm{D} 6$

${ }^{[24]} \mathrm{A} 14, \mathrm{~B} 2, \mathrm{D} 2$

${ }^{[25]} \mathrm{B} 3, \mathrm{D} 5$

${ }^{[26]} \mathrm{A} 4, \mathrm{~A} 6, \mathrm{~A} 8, \mathrm{~B} 1, \mathrm{~B} 2, \mathrm{~B} 4, \mathrm{~B} 5, \mathrm{C} 1, \mathrm{D} 3$

Responses to this article can be read online at: http://www.ecologyandsociety.org/issues/responses. $\mathrm{php} / 11342$

\section{Acknowledgments:}

This work was supported by the UK National Ecosystem Assessment Follow-On Phase, funded through WCMC. We thank all the interviewees who participated in the research.

\section{LITERATURE CITED}

Béland, D. 2005. Ideas and social policy: an institutionalist perspective. Social Policy and Administration 39(1):1-18. https:// doi.org/10.1111/j.1467-9515.2005.00421.x

Béland, D. 2009. Ideas, institutions, and policy change. Journal of European Public Policy 16(5):701-718. https://doi. org/10.1080/13501760902983382

Bryman, A. 2016. Social research methods. Fifth edition. Oxford University Press, Oxford, UK.

Carter, N. 2018. The politics of the environment: ideas, activism, policy. Third edition. Cambridge University Press, Cambridge, UK.

Challenger, A., A. Cordova, E. Lazos Chavero, M. Equihua, and M. Maass. 2018. Opportunities and obstacles to socioecosystembased environmental policy in Mexico: expert opinion at the science-policy interface. Ecology and Society 23(2):31. https://doi. org/10.5751/ES-10066-230231

Costanza, R., R. de Groot, P. Sutton, S. van der Ploeg, S. J. Anderson, I. Kubiszewski, S. Farber, and R. K. Turner. 2014. Changes in the global value of ecosystem services. Global Environmental Change 26:152-158. https://doi.org/10.1016/j. gloenvcha.2014.04.002

Department for the Environment, Food and Rural Affairs (Defra). 2011. The natural choice: securing the value of nature. Defra, London, UK.

EAC (House of Commons Environmental Audit Select Committee). 2018. HC803: The government's 25-year plan for the environment. Eighth Report of the Session 2017-2018. House of Commons, London, UK.

Eckstein, H. 1975. Case studies and theory in political science. Pages 79-138 in F. Greenstein and N. Polsby, editors. Handbook of political science. Vol. 7. Addison-Wesley, Reading, Massachusetts, USA.

Hall, P. A., and R. C. R. Taylor. 1996. Political science and the three new institutionalisms. Policy Studies XLIV:936-957. https:// doi.org/10.1111/j.1467-9248.1996.tb00343.x 
HM Government. 2016. Natural capital committee: terms of reference. HM Government, London, UK.

HM Government. 2018. Green future: our 25 year plan to improve the environment. HM Government, London, UK.

Howlett, M. 2011. Designing public policies: principles and instruments. Routledge, Oxford, UK. https://doi. org/10.4324/9781315232003

Jordan, A., and D. Russel. 2014. Embedding the concept of ecosystem services? The utilisation of ecological knowledge in different policy venues. Environment and Planning C: Politics and Space 32:192-207. https://doi.org/10.1068/c3202ed

Juntti, M., D. Russel, and J. Turnpenny. 2009. Evidence, politics and power in public policy for the environment. Environmental Science and Policy 12:207-215. https://doi.org/10.1016/j. envsci.2008.12.007

Kern, F. 2011. Ideas, institutions, and interests: explaining policy divergence in fostering 'system innovations' towards sustainability. Environment and Planning C: Politics and Space 29(6):1116-1134. https://doi.org/10.1068/c1142

King, N. 2004. Using templates in the thematic analysis of text. Pages 257-270 in C. Cassell and G. Symon, editors. Essential guide to qualitative methods in organizational research. SAGE, London, UK. https://doi.org/10.4135/9781446280119.n21

Lowndes, V. 2018. Institutionalism. Pages 54-74 in V. Lowndes, D. Marsh, and G. Stoker, editors. Theory and methods in political science. Fourth edition. Palgrave Macmillan, London, UK.

Lowndes, V., and M. Roberts. 2013. Why institutions matter: the new institutionalism in political science. Palgrave Macmillan, London, UK.

March, J. G., and J. P. Olsen. 1989. Rediscovering organisations: the organisational basis of politics. The Free Press, New York, New York, USA.

March, J. G., and J. P. Olsen. 1996. Institutional perspectives on political institutions. Governance 9(3):247-264. https://doi. org/10.1111/j.1468-0491.1996.tb00242.X

Marsh, D., D. Richards, and M. Smith. 2001. Changing patterns of governance in the United Kingdom: reinventing Whitehall? Palgrave, Hampshire, UK.

Millennium Ecosystem Assessment (MEA). 2005. Ecosystems and human well-being: synthesis. Island Press, Washington, D.C., USA.

Morgan, G. 1997. Images of organization. SAGE, London, UK.

Natural England. 2016. Nature improvement areas: about the programme. Natural England, York, UK. [online] URL: https:// www.gov.uk/government/publications/nature-improvement-areasimproved-ecological-networks/nature-improvement-areas-aboutthe-programme (accessed 24/06/2019

NEA (United Kingdom National Ecosystem Assessment). 2011. UK national ecosystem assessment: synthesis of the key findings. UNEP-WCMC, LWEC, Cambridge, UK.

Niemelä, M., and A. Saarinen. 2012. The role of ideas and institutional change in Finnish public sector reform. Policy and Politics 40(2):171-191. https://doi.org/10.1332/147084411X581871
Noe, R. R., B. L. Keeler, M. A. Kilgore, S. J. Taff, and S. Polasky. 2017. Mainstreaming ecosystem services in state-level conservation planning: progress and future needs. Ecology and Society 22(4):4 https://doi.org/10.5751/ES-09581-220404

Nordin, A. C., H. I. Hanson, and J. Alkan Olsson. 2017. Integration of the ecosystem services concept in planning documents from six municipalities in southwestern Sweden. Ecology and Society 22(3):26 https://doi.org/10.5751/ES-09420-220326

Nowell, L. S., J. M. Norris, D. E. White. 2017. Thematic analysis: striving to meet the trustworthiness criteria. International Journal of Qualitative Methods 16(1):1-16. https://doi.org/10.1177/1609406917733847

Oliver, M. J., and H. Pemberton. 2004. Learning and change in 20th century British economic policy. Governance 17(3):415-441. https://doi.org/10.1111/j.0952-1895.2004.00252.x

Parsons, C. 2016. Ideas and power: four intersections and how to show them. Journal of European Public Policy 23(3):446-463. https://doi.org/10.1080/13501763.2015.1115538

Peters, B. G. 2016. Institutionalism and public policy. Pages 57-72 in B. G. Peters and P. Zittoun, editors. Contemporary approaches to public policy. International Series on Public Policy. Palgrave Macmillan, London. https://doi.org/10.1057/978-1-137-50494-4 4

Raffaelli, D., 2016. Ecosystem structures and processes: characterising natural capital stocks and flows. Pages 62-73 in M. Potschin, R. Haines-Young, R. Fish, and R. K. Turner, editors. Routledge handbook of ecosystem services. Routledge, London, UK. https://doi.org/10.4324/9781315775302-6

Richards, D. 1996. Elite interviewing: approaches and pitfalls. Politics 16(3):199-204. https://doi.org/10.1111/j.1467-9256.1996. $\underline{\text { tb00039.x }}$

Richards, D., and M. J. Smith. 2002. Governance and public policy in the UK. Oxford University Press, Oxford UK.

Russel, D., and A. J. Jordan. 2008. The United Kingdom. Pages 247-267 in A. J. Jordan and A. Lenschow, editors. Innovation in environmental policy? Integrating the environment for sustainability. Edward Elgar, Cheltenham, UK. https://doi.org/10.4337/97818$\underline{48445062.00025}$

Russel, D., and A. J. Jordan. 2009. Joining up or pulling apart? The use of appraisal to coordinate policy making for sustainable development. Environment and Planning A: Economy and Space 41(5):1201-1216. https://doi.org/10.1068/a4142

Scharpf, F. W. 1997. Games real actors play. Actor-centered institutionalism in policy research. Westview, Boulder, Colorado, USA. https://doi.org/10.4324/9780429500275

Schmidt, V. 2008. Discursive institutionalism: the explanatory power of ideas and discourse. Annual Review of Political Science 11:303-326. https://doi.org/10.1146/annurev.polisci.11.060606.135342

Simon, H. A. 1985. Human nature in politics: the dialogue of psychology with political science. American Political Science Review 79(2):293-304. https://doi.org/10.2307/1956650

Torfing, J. 2001. Path-dependent Danish welfare reforms: the contribution of the new institutionalisms to understanding evolutionary change. Scandinavian Political Studies 24 (4):277-309. https://doi.org/10.1111/1467-9477.00057 
Turnpenny, J., M. Nilsson, D. Russel, A. Jordan, J. Hertin, and B. Nykvist. 2008. Why is integrating policy assessment so hard? A comparative analysis of the institutional capacities and constraints. Journal of Environmental Planning and Management 51(6):759-775. https://doi.org/10.1080/09640560802423541

Turnpenny, J. R., and D. J. Russel. 2017. The idea(s) of 'valuing nature': insights from the UK's ecosystem services framework. Environmental Politics 26:973-993. https://doi.org/10.1080/0964$\underline{4016.2017 .1369487}$

Waylen, K. A., K. L. Blackstock, and K. L. Holstead. 2015. How does legacy create sticking points for environmental management? Insights from challenges to implementation of the ecosystem approach. Ecology and Society 20(2):21. https://doi. org/10.5751/ES-07594-200221

Waylen, K. A., and J. Young. 2014. Expectations and experiences of diverse forms of knowledge use: the case of the UK National Ecosystem Assessment. Environment and Planning C: Politics and Space 32:229-246. https://doi.org/10.1068/c1327j

Weir, M. 1992. Ideas and the politics of bounded innovation. Chapter 7 in S. Steinmo, K. Thelen, and F. Longstreth, editors. Structuring politics. Historical institutionalism in comparative analysis. Cambridge University Press, Cambridge, UK. https:// doi.org/10.1017/CBO9780511528125.008

Weir, M., and T. Skocpol. 1985. Bringing the state back in. Cambridge University Press, Cambridge, UK. 